Author: H Sandberg

WHAT HAPPENS WHEN THE JUDICIARY SWITCHES ROLES WITH THE LEGISLATOR? AN INNOVATIVE ISRAELI VERSION OF A MIXED JURISDICTION

ISSN 1727-3781

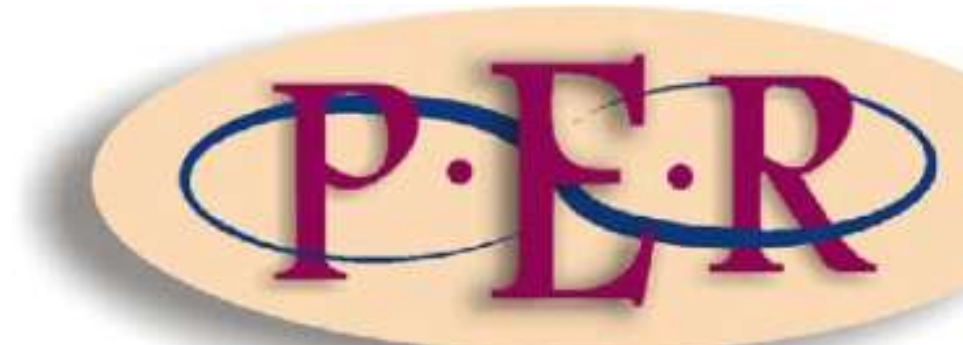

2012 VOLUME 15 No 3 


\section{WHAT HAPPENS WHEN THE JUDICIARY SWITCHES ROLES WITH THE LEGISLATOR? AN INNOV ATIVE ISRAELI VERSION OF A MIXED JURISDICTION}

\section{H Sandberg*}

\section{Introduction}

The continental civil system is distinguished from the common law by its recognised system of legislation. Both systems accept the supremacy of the statutory law over judge-made law, but statutory law still differs in its character from judge-made law. In the former, codices are analytic, abstract, and removed from the specific influence of particular cases. The solution to the particular case is derived by deduction from the abstract rule. ${ }^{1}$ In the latter, the legal rule is derived by a process of induction from a collection of specific precedents. Even when rules are codified, such as in the original English corporate legislation or the American Restatement, they reflect a collection of rulings and not a collection of analytic principles. These differences stem from the nature and the motivations of the legislative enterprise.

Civil-continental legislation originates in a legislative initiative "from above". It is driven by the aspiration for legal harmony and completeness, and was originally formulated by academics. Legislation in the common-law countries results from a "bottom up" effect in which reality dictates the nature of the developing rules, step by step. Naturally this traditional distinction has become blurred over time; certain civil law states initiate legislation in response to particular needs originating from below.

Other common law states create analytic codices, produced by groups of experts (for example, the uniform laws of the USA or the Law Commission process in England). In any event, the principle and logic of the matter is that to the extent that the legislation is more influenced by the particular circumstances of particular legal cases, as for example in the common-law systems, the law tends to be more specific

Haim Sandberg. LLB LLM LLD (Hebrew University of Jerusalem). Associate Professor, Haim Stricks School of Law, College of Management, Rishon Lezion. Email: hsandbrg@netvision.net.il. I want to thank the Research Fund of my School of Law for its generous contribution to this research.

1 The BGB had been criticised for being too abstract. Wieacker History of Private Law 377. 
and less analytic. To the extent that the legislation is the product of scientific, a priori legislation in that particular realm, and not necessarily the product of a practical need, it will be more analytic and general. The role played by the judicial branch in the formulation of legislation in common-law systems is usually specific and not general.

The traditional division of power between the judicial and the legislative branches may change in situations in which the judiciary has the authority or the power to influence the legislative agenda. Cases of this kind emerge when the judicial branch is empowered to judicially review laws, and to either strike them down or declare their incompatibility. In these cases there is a veritable role switch. In a manner resembling continent style legislation, the court reviewing existing legislation determines an abstract principle, usually in reliance on a particular constitutional text, and it is specifically the legislature that is required to distill the principles into specific legislative norms, a function normally fulfilled by the common law court. The question forming the basis of this paper is the nature of the legislative process and the legislation produced by this kind of relationship.

The paper addresses this question through the narrow prism of a concrete, in-depth examination of a particular Israeli text case - the Karsik case. ${ }^{2}$ In this case the Israeli Supreme Court handed down a fundamental ruling which entitled the original owners of land "in principle" to the restitution of their land upon the fulfillment or termination of the public purpose for which it was expropriated. Having established the principle that should guide the decision in the particular case, and at its own initiative, the Court delegated to the legislature the task of implementing and providing a specific legal arrangement based on this principle, on the basis of which the Court would then rule on the concrete case. The result was that in this particular case the traditional roles of the respective branches were reversed.

2 Karsik $v$ State of Israel HCJ 2390/96 [Isr SC] PD 55(2)625 (2001) (hereafter Karsik). The references in this article are to the formal English translation at the Supreme Court of Israel 2001 elyon1.court.gov.il. 
The paper further claims that this mechanism leads to the creation of a new variation of a "mixed-system". The judiciary abandoned its primary obligations, namely to serve as an instance for resolving disputes, while the legislature became an executor of judicially enunciated principles. The law thus enacted resembles, in its detailed and complex language, a common law text while the principle formulated in the judgment of the court resembles a section of an analytical "civil law" statute. When the motivation for legislation stems from the court's directives rather than governmental or legislative interests, the legislature or the executive branch has an interest in thwarting the legislation through various tactics. This process gives rise to the vague and detailed formula of the legislation, and guards it from assuming the abstract nature of civil law legislation. The lesson that this episode teaches us, which the courts itself internalised, is that the Court cannot really dictate a legislative agenda and it should focus on its designated role - the resolving of concrete disputes.

The first section of this article begins with a survey of the Karsik case and a presentation of the exceptional features that characterised the Court's conduct. The second section focuses on the executive and legislative response. The third section analyses the nature of legislation initiated by a judicial attempt to dictate a legislative agenda to the legislature. The article concludes with the lessons emerging from this case analysis.

\section{The roles of the judiciary reversed}

\subsection{The Karsik case}

In February 2001 the Israeli Supreme Court handed down a fundamental ruling, the Karsik case, which entitled the original owners of land "in principle" to the restitution of their land upon the fulfillment or termination of the public purpose for which it was expropriated. ${ }^{3}$ The Court's establishment of this rule resulted from an innovative

3 Karsik 60 (J Cheshin para 88). 
constitutional interpretation of an old legislation. ${ }^{4}$ Its interpretation of the legislation was inspired by the statutory provisions of the Basic Law: Human Dignity and Liberty, which is regarded in Israel as a statute with constitutional status, and states that from the point of its legislation "there shall be no violation of the property of a person" (section 3) and "there shall be no violation of rights under this Basic Law except by a law befitting the values of the State of Israel, enacted for a proper purpose, and to an extent no greater than is required" (section 8$).{ }^{5}$ The Karsik ruling was perceived, at that time, as both novel and groundbreaking. ${ }^{6}$ It was considered as such for three main reasons: Israel does not have an explicit statutory provision requiring the return of expropriated land to its owner; the Israeli Supreme Court had never ordered the return of land to an owner under similar circumstances before the enactment of the Basic Law; and the judicial review carried out by the Israeli Supreme Court on the powers of expropriation in Israel had been considered, until then, to be very moderate. ${ }^{7}$

The size of the panel deliberating on the matter attests to the importance attributed to the issue under discussion, and perhaps to the intention to send a message to the public and the executive branch concerning the importance of the ruling. ${ }^{8}$ The judgment was even translated into English for the purposes of the Supreme Court website and was displayed together with all the other judgments that the manager of the site deemed worthy of sharing with a worldwide audience. ${ }^{9}$ The judgment's innovative message was particularly well received by landowners whose lands had been expropriated, some of whom filed actions for the restitution of lands that had

4 Lands (Expropriation) Ordinance 1943 (hereafter the Ordinance); Sandberg 2010 Is L R 590 (this British Mandate legislation was the central legislative tool for state execution of land expropriations in the early days of the State of Israel).

5 Basic Law: Human Dignity and Liberty 1992; Navot Constitutional Law 45; Karsik 20, 26 (J Cheshin), 76 (J Barak), 65, 67 (J Zamir), 71 (J Strasberg-Cohen), 79 (J Dorner), 84 (J Beinisch) and 86 ( $\mathrm{J}$ Mazza).

6 Holzman-Gazit Land Expropriation in Israel 167-168; Wolff 2009 Stan J Int'l L 324.

7 Sandberg 2010 Global Jurist 21.

8 The percentage of judgments in which the Supreme Court sits in a panel in excess of five justices is extremely low. Shachar, Gross and Harris 1997 Tel-Aviv University Law Review 753.

9 Karsik, English translation. 
been expropriated, or relied upon it in pending actions or appeals, at all judicial levels. ${ }^{10}$

\subsection{The switch of roles}

As already noted, the Supreme Court's ruling in Karsik was defined as a ruling "in principle". The central criterion for evaluating a principle lies in its implementation, but in the case under discussion the Court on its own initiative delegated the task of implementing its ruling - to the legislature. Initially the Court was content to make a general call to the legislature to amend the law accordingly; the implementation of its ruling in the concrete case was deferred pending a full presentation of the petitioners' claims pertaining to various questions raised by the case, and especially the question of the retroactive application of the ruling in principle to expropriations that preceded the ruling. ${ }^{11}$ At this stage, apparently, the call to the legislature was not meant to replace the Court's substantive decision in the case at hand, and the Court still intended to rule on the case itself. ${ }^{12}$

However, with the passage of time during the progress of the legislative process, it became increasingly clear that the Court was backtracking on its intention to resolve the dispute, deferring its decision in the case on five occasions. ${ }^{13}$ Finally, the task of resolving the dispute was summarily shelved. Judith Karsik and the other petitioners were forced to wait eight years from the time that the Court gave its ruling recognising their rights "in principle" until 2009, when the Court decided to delete their petition until the legislature deigned to complete the legislation of the new expropriations law, which would give substantive and concrete substance to the

10 At least 14 cases were counted in the Supreme Court in which private owners based their claims on the Karsik precedent.

11 Karsik 61-62 (J Cheshin), 71 (J Zamir), 72 (J Strasberg-Cohen), 79 (J Barak), 79 (J Levin), 82 (J Dorner), 84 (J Beinisch), 85 (J Or) and 86 (J Mazza).

12 Karsik 62 (J Cheshin), 71 (J Zamir), 72 (J Strasberg-Cohen), 83 (J Dorner), 85 (J Or).

13 Karsik v State of Israel HCJ 2390/96 [Isr SC] Takdin-Elyon (2) 875 (2002) (2nd Karsik) 876; Karsik $v$ State of Israel HCJ 2390/96 [Isr SC] Takdin-Elyon (3) 964 (2005) (3rd Karsik) 964; Karsik v State of Israel HCJ 2390/96 [Isr SC] Takdin-Elyon (2) 3508 (2006) (4th Karsik) 3508; Karsik v State of Israel HCJ 2390/96 [Isr SC] Takdin-Elyon (2) 4727 (2007) (5th Karsik) 4727; Karsik v State of Israel HCJ 2390/96 [Isr SC] Takdin-Elyon (2) 1975 (2008) (6th Karsik) 1975. 
principle that the Court had established in its "fundamental" ruling. ${ }^{14}$ Indeed, the utilisation of the "deletion" mechanism, as opposed to "dismissal", was not prejudicial to the petitioner's rights, and prima facie they were entitled to renew their petition in the event of its transpiring that the legislature was unduly delaying the legislation. The Court similarly left open the option of challenging the constitutionality of the new legislation that was to be adopted, in addition to the option of suing for remedies provided thereunder. ${ }^{15}$ Regardless, the Court's working assumption was that the dispute would be resolved by the legislature. One year later the long-awaited law was finally enacted ${ }^{16}$ but, as will be explained in 3 , its contents were not especially related to those of the Court's ruling in principle and to a large extent actually contradicted them, in letter as well as in spirit. The practical, concrete result of the Supreme Court's move to delegate the implementation of a far-reaching and fundamental ruling to the legislature was, at least as it appears at this stage, a subversion of the fundamental ruling, and delayed justice for the parties who sought a ruling on the matter. The petitioners advocate, Alon Samuel, expressed the feelings of his clients in the following words:

Those petitioners that are still alive have a grave feeling of mistrust and serious injustice. They feel that they are used by the judicial authority to leverage itself against the Knesset [The Israeli Parliament] and the executive branch while their personal case is mistreated. ${ }^{17}$

The Court's call to the legislature in the Karsik case exposes a mode of procedure that is unique in both the Israeli and the comparative contexts. A court's deferral to the legislature is not exceptional as such, but it is usually supposed to be incidental to the court's decision on the case before it. In some cases the court's decision is of immediate effect, and the court simply makes a request to the legislature, in the wake of its ruling, to supplement lacunae or defects by way of legislation. Occasionally the court will rule on the dispute but defer the practical implementation of its decision in the particular matter, pending a more comprehensive regulation of

14 Karsik v State of Israel HC 2390/96 [Isr SC] Takdin-Elyon (1) 1743 (2009) (7th Karsik) 1743.

15 7th Karsik 1748.

16 Amendment of Land (Expropriation) Ordinance (No. 3) Law 2010 (hereafter Amendment Law).

17 Baum 2008 www.themarker.com. 
the matter by the legislature. ${ }^{18}$ In this case the Court recognised a general principle but altogether avoided any attempt to actually apply it in the case before it and in many additional cases. The Court did not rule that the land should be restored to the petitioners, but neither did it rule that it should not be restored. The Court went even further and actually sent the petitioners to present their claims to the parliament. ${ }^{19}$

\subsection{The Court as a legislator and the legislator as a judge}

The Court's conduct deviated radically from the accepted conception of its role. First, the resolution of disputes is generally regarded as the specific mandate of the judicial and not the legislative branch. The latter, in its legislative capacity, is not charged with the resolution of specific disputes, but rather with the implementation of general policies in legislation. The conventional concept of the separation of powers is that the legislature is not the appropriate body to interpret the question of the application of the law in a particular case and the conventional concept of the rule of law requires legislation to be general rather than "private" and intended for particular people. ${ }^{20}$ However, while the legislative branch is not meant to solve specific disputes, this is the court's primary role and the establishment of new rules is secondary to this role. ${ }^{21}$ Courts are obliged to rule on disputes brought before them by applying the principles of law and the judge cannot avoid ruling on a dispute that he was charged with resolving. ${ }^{22}$ The judge interpreting a statute should not (or need not) have any consideration for the legislature's "judicial conception", or for his perception of how the legislature might have decided the dispute. ${ }^{23}$

Second, the accepted concept of the separation of powers is that "legislation is the delegation of interpretation of a statute to the judiciary". ${ }^{24}$ The law establishes the principles and the judge applies them in the specific resolution of cases brought before him. It is precisely the judges who are more familiar with the particular cases

18 Mersel 2005 Mishpat Umimshal 55 ff; Rubinstein and Medina Constitutional Law 157.

19 5th Karsik 4728.

20 Rubinstein and Medina Constitutional Law 152, 287.

21 Barak General Theory 168; Gavison "Public involvement of the Supreme Court" 76.

22 Cohen v Attorney General PD 8(1) 21 (1954); Edri v Haskal PD 47(5) 337-338 (1993).

23 Barak General Theory 168.

24 Barak General Theory 193. 
in which there is a need to implement the law and this direct access and connection with the concrete cases enables them to translate the general principles set forth by the legislator into arrangements that are more specific and precise. ${ }^{25}$ The perception of the legislature as being charged with the establishment of primary arrangements also reflects the position of the Israeli Supreme Court. ${ }^{26}$

The early stages of Karsik, however, indicate a different kind of interaction. The Court unabashedly established itself as the supra-legislature that determines an abstract principle and it was specifically the legislator that was required to distill the principles into details, as though it was secondary legislation. The singularity of this conduct lies not in the fact that the Court articulated new principles and proposed to the legislature to adopt or reject them. Rather, it derives from the Court's attempt to force the legislator into adopting them by way of legislation. Whereas the call upon the legislature to legislate in accordance with the principle established and the decision to leave the file pending seems to have been an outright attempt to influence the legislative agenda, the failure to decide the case may appear to be a form of judicial restraint.

From the comparative perspective, too, a judicial mode of action whereby the court articulates a principle and abdicates its duty to give it concrete implementation is likewise exceptional. The Israeli system of judicial review enables the Supreme Court to invalidate Knesset legislation, but the Knesset for its part can, by legislation, override a ruling of the Supreme Court either by a regular or a special majority. ${ }^{27}$ In this sense it resembles the Canadian model, in which the court can strike down a law but the Parliament can override the ruling. ${ }^{28}$ This is weaker than the system accepted in the USA, where a court can invalidate a law, and its invalidation is unreviewable. ${ }^{29}$ It is stronger than the UK human rights judicial model, in which a judicial declaration of the "incompatibility" of a statute does not alter the applicable

\footnotetext{
25 Cooter Strategic Constitution 199-200.

26 Barak 2002 Harv L Rev 136.

27 Navot Constitutional Law 50.

28 Bateup 2009 Hastings Int'l \& Comp L Rev 534; s 33 Canadian Charter of Rights and Freedoms 1982, Part I Constitution Act 1982, Schedule B Canada Act 1982 (UK).

29 Bateup 2009 Hastings Int'l \& Comp L Rev 552.
} 
law for as long as the legislature has not decided to adopt it in legislation. ${ }^{30}$ It is conceded that the Karsik case was not concerned with the annulment of a law but rather with giving it a new, novel interpretation, but a new interpretation of a law may have greater long-term consequences than would its annulment, because whereas the annulment of a law can be countered by conflicting legislation, a particular interpretation of the legislation may be maintained, even when confronted with new legislation. ${ }^{31}$ The operative mode in Karsik differs from all of the modes previously described, because none of the latter included the court's abdication of its right and duty to decide. Rather than trying to analyse the reasons for this uncommon pattern of judicial behavior, we shall try in the next section to see how the other branches acted in response to the changes that the Court tried to dictate.

\section{Legislation under the Court's order}

\subsection{Executive branch rebellion}

In the parliamentary regime of the State of Israel, where the executive branch is led by the representatives of the coalition majority, a judicial initiative to delegate legislative power to the legislative authority is in theory directed at the majority controlling the parliament, and in fact at the executive branch. For as long as the parliamentary majority is stable and coalition discipline preserved, the executive authority exercises extensive power on the legislation - more so than in legal systems in which the parliament and the executive authority are separated. ${ }^{32}$ Legislative initiatives in Israel generally begin with the Government and even private members' bills will ultimately be navigated by the executive branch. ${ }^{33}$ Indeed, politicians representing the public are at the apex of the executive branch, but the legislative process is ultimately channeled into the workings of the governmental civil service that actually formulates the concrete details of policies. The legislative process that the court initiated began with civil servants and only eventually did it reach the parliamentary labyrinth.

30 Bateup 2009 Hastings Int'l \& Comp L Rev 543; s 4 Human Rights Act 1998 (UK).

31 Bateup 2009 Hastings Int'l \& Comp L Rev 543, 571-572.

32 Cooter Strategic Constitution $215 \mathrm{ff}$.

33 Rubinstein and Medina Constitutional Law 170 (fn 179); Zilber Bureaucracy as Politics 31-32. 
Civil servants or bureaucrats are no doubt subordinate to the directives of politicians, but they evince a natural tendency to enlarge the organisations they control as well as the resources and powers at their disposal. ${ }^{34}$ It is only natural that the state authorities charged with the administration of state assets will seek to perpetuate their control of the inventory of government assets, in addition to retaining maximal freedom of action in exercising their purchasing powers for public purposes in order to enlarge it. This consideration may reflect a particular social or economic policy of the public representatives, but it may also be of independent standing deriving from the nature of the organisation controlling the assets, and may tip the scale in favour of retaining assets in excess of what would be required in terms of public policy. ${ }^{35}$ The significance of this consideration may increase when the guidelines of political policy are not clearly delineated, or when the governmental bureaucracy is granted a large measure of discretion, or when there are frequent replacements at the political - ministerial level. ${ }^{36}$ These factors may well whet the bureaucracy's desire to thwart the judicial directive to enact a law that would formalise the restitution of assets from the state to their private owners.

The executive branch is obviously obliged to respect the judicial branch, but even so, both the branch and its bureaucrats may have their own strategic considerations. The executive branch may be likely to weigh up the probable response of the judicial branch to a move that would foil its initiatives. It will try to avoid a direct conflict with the court by using a strategy based on circuitous tactics in order to thwart the judicial directive, without disclosing its real, covert motivation.

Such considerations originating in the senior bureaucracy of the executive branch are discernible in its treatment of the Supreme Court's guidelines in the Karsik case. One of the informal tools for the derailing of a judicial directive is the delaying of its execution. ${ }^{37}$ This kind of delay may reduce public interest in the issue or simply

34 Zilber Bureaucracy as Politics $43 \mathrm{ff}$; Cooter Strategic Constitution 152.

35 The former president of the Supreme Court, Justice Aharon Barak, described, in one of his books, the Treasury's initiative to enact a law that was meant to change the judicial interpretation given to existing tax legislation as an activity of a "pressure group". Barak Statutory Interpretation 76.

36 Cooter Strategic Constitution 166-167.

37 Bateup 2009 Hastings Int'l \& Comp L Rev 553 (text after fn 92). 
postpone the directive in anticipation of planned or unplanned changes in the positions of the public representatives or the judges themselves. The time period between the handing down of the ruling of the Karsik case and the enactment of the much-awaited amendment as well as personal changes in the composition of the panel and the composition of the legislative and executive branches all attest to the success of this tactic. ${ }^{38}$

Another tool for camouflaging the move to thwart the judicial ruling was rerouting it to the path of a professional examination as opposed to an examination of political policy considerations. In July 2001, five months after the Court had called for the enactment of a new expropriations law, the incumbent Minister of Finance charged an "inter-ministries committee" with the evaluation of the change. ${ }^{39}$ Prima facie the establishment of the Committee constituted an achievement for the Court, because it would not have been established if not for the Court's call to the legislature. The committee's founding document explicitly stated that the court's reference to the legislature was the reason for its establishment. ${ }^{40}$

All the same, the very establishment of the Committee presaged the direction it would take. First, an "inter-ministries" committee consists exclusively of bureaucrats who dictate its positions. Its membership does not include those who represent other interests or who are by definition independent. Neither did the Committee include so much as a single independent expert, lawyer, land appraiser, planner, academic, judge or retired judge with expertise in the disciplines related to the committee's mandate, and who was not a governmental civil servant. ${ }^{41}$ The only representative who was not a bureaucrat was the legal advisor of the Tel-Aviv Municipality, who was also an employee of a body which is usually the executor of expropriations and not their victim. The Committee's composition lacked any representation of various

38 All judges (except $\mathrm{J}$ Beinisch) who were members of the panel that ruled the first Karsik case retired during the nine years that followed. At the same time five different governments and four terms of the Knesset came and went.

39 Israel Ministry of Finance 2004 www.finance.gov.il Cover letter (Inter-ministries Committee Report).

40 Inter-ministries Committee Report Cover letter.

41 Inter-ministries Committee Report Cover letter. Although the committee hired an Israeli expert jurist to make a comparative study and invited another opinion from a German expert, both were not members of the committee. 
bodies in the private sector that might have had an interest in the matter, and conspicuously refrained from inviting the public to express its views on the matters under discussion.

In contrast to the non-representation of independent representatives, there was a conspicuous majority of state employees on the Committee, all of them representatives of the central government ministries charged with the administration of state assets: legal advisors of the Finance Ministry, the Construction and Residence Ministry, the National Infrastructures Ministry, the Israel Land Administration authority, the National Roads Company, and the Deputy Supervisor of Budgets in the Finance Ministry. ${ }^{42}$ In addition there were two civil servants from the Ministry of Justice, who in view of the composition of the Committee were the only members who did not represent an interested government ministry. ${ }^{43}$ In fact, when a dispute emerged between the Committee members concerning the justification for a right to restitution in cases of failure to realise the public purpose of the expropriation it was precisely the representatives of the Justice Ministry who supported restitution, whereas the representatives of the ministries administering the assets supported its negation and its limitation to the right to repurchase the asset. ${ }^{44}$

The composition of the Committee may have portended that its work would not result in stronger expression being given to the interests of the original land owners (which at least in terms of the public expectation were supposedly reflected in the Court's original decision), and that instead it would protect the interests of the relevant ministries. It may be assumed that the filling of positions in the Committee was not left to chance, being instead the product of intentional planning. The Committee's composition did in fact influence the format of its deliberations. Ultimately the Committee produced a recommendation that led to the enactment of a law that thwarted the Karsik ruling, as expected and as described below.

42 Inter-ministries Committee Report Cover letter.

43 Inter-ministries Committee Report Cover letter.

44 Inter-ministries Committee Report 37-42. 
The anchoring of government policy in the conclusions of a "committee" bestows a professional or even scientific character on the government decision and totally disguises the interest-biased character of a government decision that tends to preserve resources under the control of bureaucrats. Indeed, bureaucrats cannot dictate their wishes to the political level to which they report, but the establishment of a committee may confer greater immunity against interference upon their recommendations. During the discussions in the Knesset's finance committee the state's legal advisors based their arguments on the recommendations of the Interministries Committee or the lack thereof. For example, when the chairman of Real Estate Appraisers Association offered to put into the new law an "expropriation compensation clause" the Treasury's representative responded: "... It is not the subject that the Inter-ministries committee even discussed". ${ }^{45}$ When the chairman offered to set deadlines for the expropriation, the Government representative replied: "The Inter-ministries committee had already heard the authorities which deal with these things". 46

Public support plays an important role in such a matter. The public may view the decisions of a professional "civil servant" as ultimately professional and free of any alien considerations, whereas a politician's attempts to alter and/or detract from a committee's recommendations may be perceived as being motivated by alien interests. From the politician's perspective this public perception may have negative electoral repercussions and thus deter him from introducing changes into a proposal of the civil service, notwithstanding the "purity" of his motives. Information on the attitudes of Israeli citizens that was collected, on the basis of a random sample of the adult population (aged 18 years or older), in surveys that were conducted continuously every year from 2001 indicates that Public confidence in the Knesset, Knesset members, government ministers and political parties is consistently lower than public trust in governmental institutions and government officials. ${ }^{47}$ Civil servants do indeed usually work on behalf of the public. By virtue of their professional training, their period of service and experience they have a professional

45 Finance Committee Protocol (26.10.2009) 11; Finance Committee Protocol (8.12.2009) 41.

46 Finance Committee Protocol (26.10.2009) 26 (Treasury representative); Finance Committee Protocol (9.11.2009) 3 (Ministry of Justice's representative).

47 Vigoda-Gadot and Mizrahi 2009 cpmp.hevra.haifa.ac.il 32, 39. 
advantage over the political level, which is subject to frequent changes on the personal level. All the same, the fact that the process of producing decisions is seemingly a serious and professional one of a "committee" does not necessarily immunise the committee and its decisions from overt or covert policy considerations.

The formulation of the recommendations of the civil service may similarly affect the chances of altering the formulation at more senior levels. For example, the formulation of the recommendations in a manner offering a choice between alternatives informs the eventual decision makers of the existence of different policy options and enables them to prefer the option most appropriate in their own eyes. On the other hand, a "take it or leave it" formulation, as most of the recommendations were worded in the case in point, makes it difficult to reject the recommendations. In such a case, no alternatives may be offered, and a relatively large measure of daring and initiative would be required in order to disqualify the only alternative up for discussion. ${ }^{48}$ This is nicely demonstrated by the deft wording of the recommendations of the Inter-ministries Committee concerning the nature of the right to restitution conferred as a result of a failure to realise the public purpose of the expropriation. Rather exceptionally, and due to a dispute between its members, the Committee report presented one alternative under which the land would be restored to the original owner and another alternative which would give him only the right to repurchase the land. ${ }^{49}$ This presentation of alternatives enabled the Finance Minister to choose the option of restitution, which was closer to the spirit of the Karsik ruling, and this option was actually included in the memorandum of the law that was disseminated to the public. ${ }^{50}$ An internal dynamic, however, the nature of which is not clear, but which was presumably influenced by the existence of documentation of different alternatives, ${ }^{51}$ led the Government finally to adopt the more limited option -

48 Cooter Strategic Constitution 218.

49 Inter-ministries Committee Report 37-42.

50 Section 14B(b), Memorandum of Amendment to Land (Expropriation) Ordinance (Amendment No. 3) 2004-5765. A copy is saved with the author.

51 Finance Committee Protocol (26.10.2009) 7 (Advocate Dorfman of the Knesset Finance Committee informs the committee about the government decision without any reference to the apparent change from the wording of the memorandum but with reference to the limited option in the Inter-ministries Committee Report). 
the right to repurchase. ${ }^{52}$ This may have been the amendment of a tactical "error" that occurred in the course of presenting the two alternatives to the decision makers.

We see that the first and most significant barrier that the judicial order has to overcome is the opposition of the government bureaucracy, which naturally had no motivation to implement an agenda that was not initiated in the government ministries. These civil officers used an arsenal of tools to immunise its recommendations against the interference of both the elected policy makers and the court. As we shall see in the next paragraph, while these techniques did not absolutely entrench the recommendations against a deeper legislative examination, it reduced the chances that such an investigation would actually enable the thwarting of its recommendations.

\subsection{The legislature caught between the executive branch and the judiciary}

The significant weight of the senior civil service in the formulation of the subversive bill found expression in the discussions of the Knesset's Finance Committee in preparing the law for a vote in the plenum, in which the representatives of the bureaucracy were both numerically and substantively dominant. ${ }^{53}$ The central sources of opposition to the bureaucrats, expressing positions in favour of the restitution of expropriated lands, were the representatives of two interest groups that stood to benefit from the Karsik ruling - a representative of the Bar Association, and representatives of the Land Appraisers Bureau. ${ }^{54}$ The direct victims of the Karsik case who, it will be recalled, were sent by the Court to present their cases before the legislature, were far more modestly represented and in fact had no influence on the

52 Section 14B(b) Draft Bill of Land (Expropriation) (Ordinance) (Amendment No. 3) 2006 (Draft Bill).

53 Representatives of Ministries of Finance, Justice and Housing and representatives of Israel Land Administration, National Roads Company and The National Railway Company participated in most if not all these discussions.

54 The most prominent voice in favour of land owners was made by the Bar Association representative, attorney Yoram Hajbi, and representatives of the Real Estate Appraisers Association (chairman Erez Cohen, his legal adviser and the appraiser Nehama Bugin). They participated very actively in almost all meetings. 
result. ${ }^{55}$ They lacked the backing of any powerful and influential organisation that could have accepted the challenge and persuaded the legislature to support their cause. ${ }^{56}$ This may be perfectly illustrated by the following discussion between the chairman of the Finance Committee, MK Gafni, and Advocate Alon Samuel, who represented some of the petitioners in the Karsik case itself and attended the last meeting (15.12.2009). In the beginning of this last meeting, just before the committee was prepared to vote on the final version of the law, the chairman gave Samuel the right to speak: "Advocate Alon Samuel, I'll give you a minute or two to talk, even though we had finished our discussion. Knesset speaker asked and I will give you that". Immediately after Samuel had finished, the committee came to a vote. ${ }^{57}$

While many reservations to the Government bill naturally came from leftwing opposition parties, the opposition naturally did not have much chance of forcing an alteration of a dictat on the part of the executive branch, and all of their proposed amendments were rejected. ${ }^{58}$ Barring the chairman of the Finance Committee and its deputy, only left-wing opposition Knesset members sought permission to speak during the plenary discussion before the Knesset plenum. ${ }^{59}$ As opposition M.K (Member of Knesset) Oron testified, "Nothing will pass in the plenum. The automatism in the plenum is one hundred times greater". ${ }^{60}$

55 Advocate Moshe Shuv, who represented some of the petitioners whose petitions were pending before the Supreme Court, participated in three meetings (02.12.2009, 14.12.2009, 15.12.2009); Professor Shlomo Bunimovitz, heir of the land expropriated on "Pi-Glilot" site in Tel- Aviv, who was also a party to a petition that lay before the Supreme Court, participated in two meetings (12.07.2009, 14.12.2009).

56 For an analysis of the different but significant roles that libertarian NGOs played in supporting the wave of statutory amendments of expropriation laws that spread over USA after Kelo, see Nadler, Seidman Diamond and Patton "Government Takings of Private Property" 302.

57 Finance Committee Protocol (15.12.2009) 2.

58 The amendments included proposals to allow restitution even when the purpose of the purchase was realised on most of the expropriated area but not entirely (MK Swede), to prevent a subsequent change of the public purpose (MK Swede, Yachimovich and Oron), or to apply the law on expropriation retrospective to the founding of the state (Oron and Swede). Finance Committee Protocol (14.12.2009) 55; Finance Committee Protocol (15.12.2009) 9-10.

59 Two MKs in the first plenary discussion (Bashara and Tibi) and five in the second and third plenary discussions (Oron, Yachimovich, Tibi, Zahalka and Swede). Records of the 74th Session of the 17th Knesset 5058-5061; Records of the 107th Session of the 18th Knesset 68-108.

60 Finance Committee Protocol (14.12.2009) 57. 
But the members of the government did not have much success in defeating the bureaucrats either. It is usually the coalition parties with a right-wing economic orientation that are expected to guard the interests of private property, but in this case the tables were reversed and it was the left-wing parties that attempted to represent them. This anomaly was well described by MK Yachimovich (Israel Labour Party) in the words:

According to my world view, which is a social-democratic...the public needs often prevail over property right of a person, and it is right to expropriate land from a private person for the sake of the entire public... But if the expropriated land is not used any more for public purposes, then if you do not return it and make it tradable asset ... I think that there is most severe harm in the sense of justice... This thing is not good, not worthy. Land should be returned to its owner immediately after the end of the public purpose for which it was taken. ${ }^{61}$

The impression derived from the deliberations is that none of the MKs saw themselves as enthusiastic supporters of the Government bill, and even the members of the coalition saw themselves as being subject by the Government's dictates, which were nothing but the dictates of the civil service. "One might have thought that this was our draft bill. This is the Government's bill", said Chairman Gafni, the Committee Chairman, to his colleague from the opposition, Haim Oron. ${ }^{62}$ And elsewhere: "I'll do what the Government says. I'm not going to battle with the Government over this; I'll go to battle with the Government on other matters". ${ }^{6}$ It thus comes as no surprise that none of the participants in the legislative process was able to overcome the main, obstructive elements of the Government's bill, as originally formulated by the Inter-ministries Committee.

Knesset members succeeded in introducing only a few minor changes in the bill within the spirit of the judicial order, and primarily in contexts where there was recorded evidence of a dispute among the representatives of the executive civil service. During the deliberations of the Finance Committee the Knesset Members were informed of such a dispute in the recommendations of the Inter-ministries

61 Records of the 107th Session of the 18th Knesset 86.

62 Finance Committee Protocol (14.12.2009) 13.

63 Finance Committee Protocol (8.12.2009) 17. 
Committee ${ }^{64}$ and the result was that the Committee Chairman drafted a preliminary position in favour of the more liberal option. ${ }^{65}$ This formed the basis of a draft that he submitted for discussion by the secondary commission established for the preparation of the law. In the course of the debate numerous references were made to the two alternatives presented in the Committee's report. ${ }^{66}$ This position, the result of a breach in the otherwise united front presented by the executive branch, was the central achievement of the Committee, regarding which the Committee Head could congratulate himself, saying that "this is something that we have battled for"67 and later "...don't say that the Finance Committee is a mere rubber stamp. We succeed in changing things." 68 Yet at the end of the day a "compromise" proposal was adopted under which restitution would be limited to much fewer cases. ${ }^{69}$

\section{The results of the reversal of roles}

\subsection{The nature of the new law}

Despite this minor success the Amendment ${ }^{70}$ actually derailed the broad principle determined by the Court. The new law realises the meta-principle established by the Court in a particularly limited form and to large extent actually contradicts it, in letter as well as in spirit. Its transition provisions sealed the fate of the petitioners' rights, stating unequivocally that the law would not apply where the public purpose had been fulfilled before its commencement. ${ }^{71}$ These provisions rendered the new law almost totally irrelevant, given that most of the expropriations under the original Ordinance were carried out up until the eighties, and that the State has made sparing use of the tool of expropriations under the Ordinance over the past few

64 Inter-ministries Committee Report 37-42.

65 Finance Committee Protocol (26.10.2009) 6.

66 Finance Committee Protocol (9.11.2009) 6.

67 Finance Committee Protocol (8.12.2009) 24.

68 Finance Committee Protocol (15.12.2009) 4. This achievement was presented by MK Gafni in the beginning of the speech in which he presented the bill for final voting in the Knesset's plenum. Records of the 107th Session of the 18th Knesset 70.

69 Finance Committee Protocol (8.12.2009) 32 and Finance Committee Protocol (14.12.2009) 3.

70 Amendment Law.

71 Section 27(b)(1) Amendment Law. The lands of the petitioners had been expropriated more than forty years earlier. Karsik 6 (Notices of expropriation were published on 25.12.1958, 27.2.1959 and 24.3.1966). 
decades. ${ }^{72}$ The amended Ordinance does not confer upon the land owners a right to the restitution of the land, but rather a right to purchase the asset anew for the current market value in the event that in future, after the law's enactment, the purpose of the expropriation is fulfilled and then expires. ${ }^{73}$ The practical probability of any land owners actually benefitting from these rights is thus particularly low. The new law realises the meta-principle established by the Court in a particularly limited form. Evidently, the senior bureaucrats of the executive branch marked up a "strategic victory" in the campaign to foil the Karsik ruling.

Another more formal characteristic of the new law is its vagueness. Its provisions are particularly cumbersome, so much so that occasionally it seems that its drafters sought to conceal its limiting approach in a maze of complex and obscure provisions. For example, the two sections containing the most narrowing affect on the rights purportedly conferred by the statutory amendment are actually tucked away into two marginal subsections deep within a thick forest of provisions. ${ }^{74}$

While it may be conceded that the Court's directive and the legislative mandate were not limited to the specific subject treated of in Karsik, the new law actually focused on that particular subject. For example, the Committee and hence the legislator decided not to consider the implications of the Karsik ruling on expropriations under the Planning and Construction Law, which today is the central tool for the execution of expropriations. ${ }^{75}$

It seems that when the Court and the legislature switch roles the law that is produced cannot detract from its judicial origin. The law thus enacted resembles in its detailed and complex language a common law text, while the principle formulated in the judgment of the court resembles a section of an analytical "civil law" statute. It is

72 Adv Eynat Kaufman of the Israel Land Administration (ILM) reported to the Knesset that only 30 expropriations with a total area of 20,000 dunams had been executed since 1981, while 385,000 dunams had been expropriated before 1981. Finance Committee Protocol (14.12.2009) 43.

73 Section 14B The Ordinance (after amendment).

74 For example, the transitional provisions that effectively deny retroactive application of the new amendment are not included in the revised Ordinance but only in the amending law. Other important reservations to the apparent right of restitution are hidden in sub-sections $14 \mathrm{D}(\mathrm{b})$ or $14 \mathrm{~B}(\mathrm{j})(1)-(2)$.

75 Inter-ministries Committee Report 5. 
connected to the circumstances of the case from which it originates. The famous maxim "hard cases make bad law" may be fairly applied to this peculiar statutory result.

\subsection{The Court draws its lessons}

The Supreme Court was aware both of the thrust of the arrangement proposed and the involvement of the executive branch in its formulation. On a practical level, however, the Court preferred to ignore the fact that these proposals contradicted the principle that it had determined. After the Knesset approved the amendment in its final restrictive wording the Court was actually released from the need to address the issue of retroactivity, which prima facie was the only question remaining for resolution in the wake of the original ruling "in principle". Even if the Court continues to claim that the amendment's constitutionality is still open for a decision, it seems that the Court has reconciled itself to the legislation. ${ }^{76}$

However, the Court did in fact draw the lesson from the case. In the recent Even Zohar $^{77}$ case the Court had another opportunity to adopt the Karsik format, but this time the Court avoided the attempt to dictate an agenda to the legislature. The question of principle in this case likewise concerned expropriations, and in a context no less fundamental than that of the Karsik case: the question was whether or not an order of the military closure and requisition of private land entitles the aggrieved land owner to compensation. ${ }^{78}$ The requisition was carried out under an old law which contains no explicit provision granting a right of compensation to the aggrieved landowners. ${ }^{79}$ All of the justices agreed that the application of the existing law was

76 In a recent case Chief Justice Beinicsh relied on the transition provisions in the Amendment Law but did not relate specifically to the question of the constitutionality of this law simply because "this question is not before us in this petition". Avney Derech v Minister of Finance HCJ 9614/03 [Isr SC] Takdin-Elyon (4) 2902, 2906 (2010). Justice Meltzer "noted" that the "ruling was here then, inter alia, on the assumption that the amendment was constitutional, but this assumption had not been tested" (at 2907).

77 Even Zohar v State of Israel CA 2281/06 [Isr SC] Takdin-Elyon (2) 1241 (2010).

78 Even Zohar $v$ State of Israel CA 2281/06 [Isr SC] Takdin-Elyon (2) 1241 (2010) 1242 (the case referred to immovable property which was adjacent to a wide military training facility (a shooting range) which runs along the coast south of Rishon-Le-Zion to Palmahim).

79 Defense (Emergency) Regulations 1945. 
not desirable, that it is inconsistent with the spirit of Basic Law and that the legislature would do well to amend it. Nonetheless, Justice Danziger was the only justice who proposed adopting the Karsik-technique - the establishment of a fundamental principle compelling compensation and the postponement of the legal proceeding until its legislative implementation. He enlisted the same reasons that served for the postponement of the ruling in the Karsik case. ${ }^{80}$ The majority of the justices were not prepared to adopt this technique in either of its aspects, despite their agreement that the matter indeed merited a legislative - and not a judicial solution. Justice Procaccia said that "Arrangements of this kind should be established at the level of primary legislation, and are not a natural part of the judicial act". ${ }^{81}$ Justice Jubran concluded:

We cannot get into the principle issue. It is the job of the legislature who should act to adjust the spirit of the law in question to the legal and social concepts of today. ${ }^{82}$

Hence the Court dismissed the case. ${ }^{83}$

\section{$5 \quad$ Conclusions}

The Karsik case was a unique attempt of the judicial branch to dictate a detailed legislative agenda. This attempt did not succeed - and not surprisingly. The Court lacks the ability to impel the legislature to regulate an abstract principle in an analytic format similar to what is customary in the Civil-Law-Continental countries. At the end of the day the power to legislate rests with the legislature, and especially in a parliamentary system, with the executive branch. If a parliamentary majority wishes to thwart a legislative initiative, or when the sovereign administration has an interest in thwarting it, they possess the tools to do so in an effective manner, i.e. procrastination, the appointment of an inter-ministries committee, and the (intentionally) obscure formulation of the thwarting legislation.

80 Even Zohar v State of Israel CA 2281/06 [Isr SC] Takdin-Elyon (2) 1241 (2010) 1261.

81 Even Zohar v State of Israel CA 2281/06 [Isr SC] Takdin-Elyon (2) 1241 (2010) 1272.

82 Even Zohar v State of Israel CA 2281/06 [Isr SC] Takdin-Elyon (2) 1241 (2010) 1268.

83 The appellants' request for a second hearing of the case has recently been denied. Even Zohar $v$ State of Israel SCA 5151/10 [Isr SC] Takdin-Elyon 2010 (4) 1444 (2010). 
The switch of roles in the case analysed apparently led to the creation of a new variation of a "mixed-system". The judiciary abandoned its primary obligations, namely to serve as an instance for resolving disputes, while the legislature became an executor of judicially enunciated principles. The law thus enacted resembles a common law text in its detailed and complex language, while the principle formulated in the judgment of the court resembles a section of an analytical "civil law" statute. Yet the lesson that this episode teaches us, which the court itself internalised, emphasises the common ground of both the Civil Law and Common Law systems the Court cannot dictate a legislative agenda and it should focus on its designated role - the resolving of concrete disputes. 


\section{Bibliography}

Barak General Theory

Barak A Interpretation in Law - Vol 1: General Theory (Nevo Jerusalem 1992) [in Hebrew]

Barak Statutory Interpretation

Barak A Interpretation in Law - Vol 2: Statutory Interpretation (Nevo Jerusalem 1993) [in Hebrew]

Barak 2002 Harv L Rev

Barak A "A Judge on Judging: The Role of a Supreme Court in a Democracy" 2002 Harv L Rev 16-162

Bateup 2009 Hastings Int'l \& Comp L Rev

Bateup C "Reassessing the Dialogic Possibilities of Weak-Form Bills of Rights" 2009 Hastings Int'l \& Comp L Rev 529-599

Cooter Strategic Constitution

Cooter RD The Strategic Constitution (Princeton University Press Princeton 2000)

Gavison "Public Involvement of the Supreme Court"

Gavison R "Public Involvement of the Supreme Court" in Gavison R, Kremnitzer $M$ and Dotan $Y$ (eds) Judicial Activism: For and Against (Magnes Hebrew University Press Jerusalem 2000) 69-164 [in Hebrew]

Holzman-Gazit Land Expropriation in Israel

Holzman-Gazit Y Land Expropriation in Israel: Law Culture and Society (Ashgate Aldershot 2007) 
Mersel 2005 Mishpat Umimshal

Mersel Y "Suspending the declaration of invalidity" 2005 Mishpat Umimshal Law and Government in Israel 39-102 [in Hebrew]

Nadler, Seidman Diamond and Patton "Government Takings of Private Property" Nadler J, Seidman Diamond S and Patton MM "Government Takings of Private Property" in Persily N, Citrin J and Egan P (eds) Public Opinion and Constitutional Controversy (Oxford University Press Oxford 2008) 286-309

Navot Constitutional Law

Navot S The Constitutional Law of Israel (Kluwer Alphen aan den Rijn 2007)

Rubinstein and Medina Constitutional Law

Rubinstein A and Medina B The Constitutional Law of the State of Israel Volume $A$ 6th ed (Schocken Jerusalem 2005) [in Hebrew]

Sandberg 2010 Global Jurist

Sandberg $\mathrm{H}$ "Legal Colonialism - Americanization of Legal Education in Israel" 2010 Global Jurist Issue 2; Article 6

Sandberg 2010 Is L R

Sandberg $\mathrm{H}$ "Land Expropriations of Private Arab Land in Israel - An Empirical Analysis of the Regular Course of Business" 2010 Is $L R$ 590-610

Shachar, Gross and Harris 1997 Tel-Aviv University Law Review

Shachar Y, Gross M and Harris R "Anatomy of Discourse and Dissent in the Supreme Court - Quantitative Analyses" 1997 Tel-Aviv University Law Review 749-795 [in Hebrew

Wieacker History of Private Law

Wieacker F A History of Private Law in Europe (translated from the original German by Tony Weir) (Clarendon Press Oxford 1995) 
Wolff 2009 Stan J Int'I L

Wolff DJ Book Note 2009 Stan J Int'l L 321-324

Zilber Bureaucracy as Politics

Zilber D Bureaucracy as Politics (Nevo Jerusalem 2006) [in Hebrew]

\section{Register of case law}

Avney Derech v Minister of Finance HCJ 9614/03 [Isr SC] Takdin-Elyon (4) 2902 (2010) [in Hebrew]

Cohen v Attorney General CA 238/53 [Isr SC] PD 8(1) 4 (1954) [in Hebrew]

Edri v Haskal CA 595/88 [Isr SC] PD 47(5) 333 (1993) [in Hebrew]

Even Zohar v State of Israel CA 2281/06 [Isr SC] Takdin-Elyon (2) 1241 (2010) [in Hebrew]

Even Zohar $v$ State of Israel SCA 5151/10 [Isr SC] Takdin-Elyon 2010(4) 1444 (2010) [in Hebrew]

Karsik v State of Israel HCJ 2390/96 [Isr SC] PD 55(2)625 (2001) [in Hebrew] (In short Karsik)

Karsik v State of Israel HCJ 2390/96 [Isr SC] Takdin-Elyon (2) 875 (2002) [in Hebrew] (In short 2nd Karsik)

Karsik v State of Israel HCJ 2390/96 [Isr SC] Takdin-Elyon (3) 964 (2005) [in Hebrew] (In short 3rd Karsik)

Karsik v State of Israel HCJ 2390/96 [Isr SC] Takdin-Elyon (2) 3508 (2006) [in Hebrew] (In short 4th Karsik)

Karsik v State of Israel HCJ 2390/96 [Isr SC] Takdin-Elyon (2) 4727 (2007) [in Hebrew] (In short 5th Karsik)

Karsik v State of Israel HCJ 2390/96 [Isr SC] Takdin-Elyon (2) 1975 (2008) [in Hebrew] (In short 6th Karsik)

Karsik $v$ State of Israel HC 2390/96 [Isr SC] Takdin-Elyon (1) 1743 (2009) [in Hebrew] (In short $7^{\text {th }}$ Karsik) 


\section{Register of legislation}

\section{Canada}

Canadian Charter of Rights and Freedoms 1982

Constitution Act 1982

Canada Act 1982 (U.K.)

\section{Israel}

Amendment of Land (Expropriation) Ordinance (No. 3) Law 2010

Basic Law: Human Dignity and Liberty 1992

Defence (Emergency) Regulations 1945

Lands (Expropriation) Ordinance 1943

\section{UK}

Human Rights Act 1998

\section{Register of government publications}

Draft Bill of Land (Expropriation) (Ordinance) (Amendment No. 3) 2006

Finance Committee Protocol (26.10.2009) [in Hebrew]

Finance Committee Protocol (9.11.2009) [in Hebrew]

Finance Committee Protocol (8.12.2009) [in Hebrew]

Finance Committee Protocol (14.12.2009) [in Hebrew]

Finance Committee Protocol (15.12.2009) [in Hebrew]

Records of the $74^{\text {th }}$ Session of the $17^{\text {th }}$ Knesset 10 Divrei HaKnesset (19.12.2006) [in Hebrew]

Records of the $107^{\text {th }}$ Session of the $18^{\text {th }}$ Knesset (08.2.2010) [in Hebrew]

\section{Register of internet sources}

Baum 2008 www.themarker.com

Baum I 2008 'H.C. Karsik: Who will defend the property rights of the land owners in Givaat Olga?' De-Marker 14 September 2008 
www.themarker.com/tmc/article.jhtml?Elementld=skira20080914_1020796 [date of use 9 Sep 2012]

Israel Ministry of Finance 2004 www.finance.gov.il Israel Ministry of Finance 2004 Report of the Inter-ministries Committee for the Change of the Land (Expropriation) Ordinance 1943 www.finance.gov.il/karka.htm [date of use 9 Sep 2012]

Supreme Court of Israel 2001 elyon1.court.gov.il

Supreme Court of Israel 2001 Karsik $v$ State of Israel (English translation) elyon1.court.gov.il/files_eng/96/900/023/g10/96023900.g10.htm [date of use 9 Sep 2012]

Vigoda-Gadot and Mizrahi 2009 cpmp.hevra.haifa.ac.il

Vigoda-Gadot E and Mizrahi S 2009 Israeli Public Sector Performance: Citizens' Attitudes Analysis and National Assessment [in Hebrew] cpmp.hevra.haifa.ac.il/admin/uploads/files/NAPPA-IL-09.heb.pdf [date of use 9 Sep 2012]

\section{List of abbreviations}

Harv L Rev

Hastings Int'l \& Comp L Rev

ILM

Is L R

Stan J Int'I L
Harvard Law Review

Hastings International and Comparative Law Review Israel Land Administration Israel Law Review Stanford Journal of International Law 